2. To: (Receiving Organization)

B Plant Facility Engineering

5. Proj./Prog./Dept./Div.:

B Plant

8. Originator Remarks:

Document issued for approval and release.

11. Receiver Remarks: 11A. Design Basel ine Document? [] Yes [X] No The attached safety assessment establishes the safety basis for the storage and use of phosphoric acid at the B PTant facility.

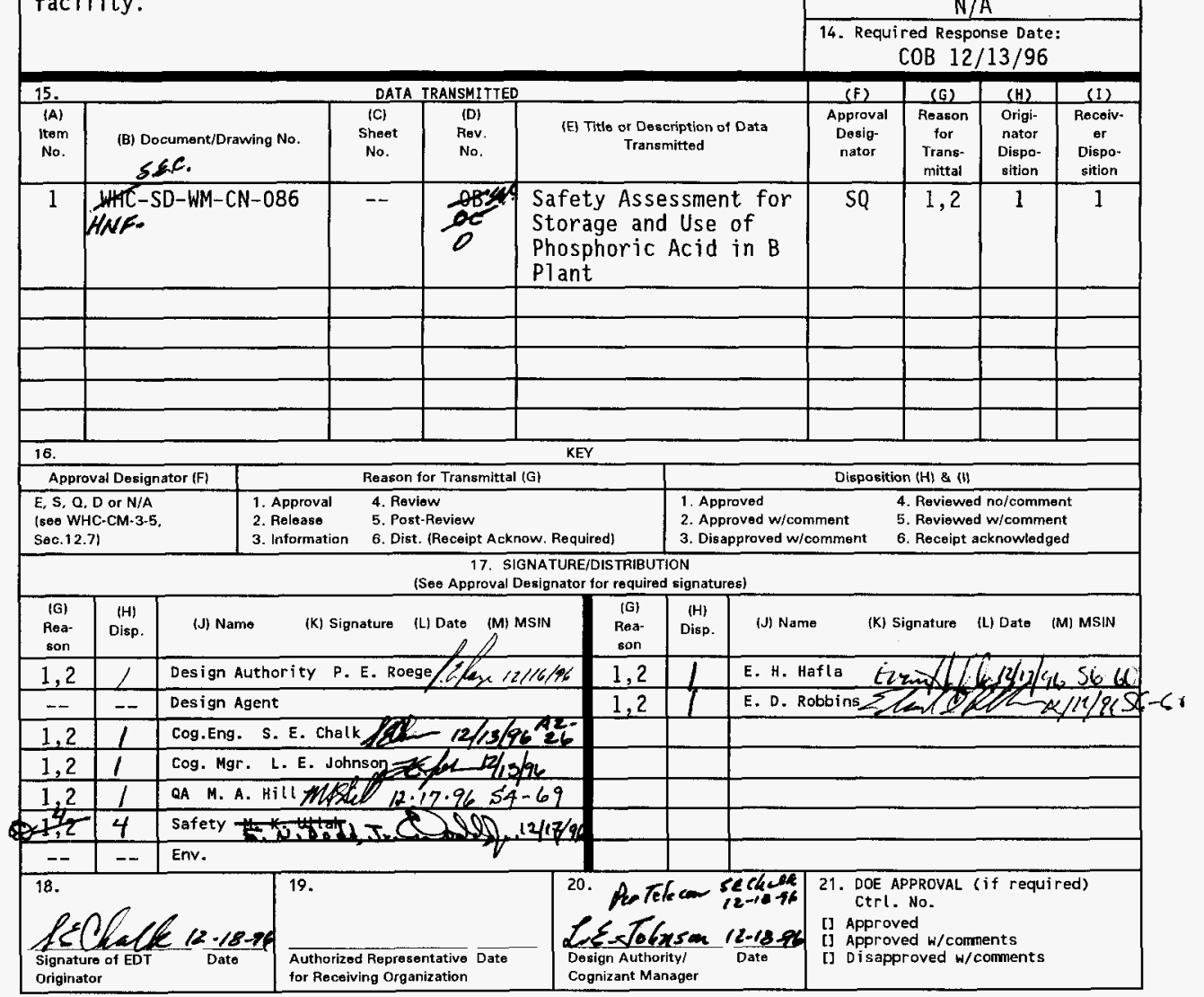

BD-7400-172-2(05/96) GEF097 


\section{Safety Assessment for Storage and Use of Phosphoric Acid in B Plant}

Los Alamos Technical Associates, Inc., Rich] and, WA 99352

John P. Joyce

U.S. Department of Energy Contract DE-AC06-96RL13200

EDT/ECN: $6162^{4} 77619952$ UC: 510

Org Code: 403 Charge Code: KN24F

B\&R Code: EW3135090 Total Pages: 35

Key Words: USQ, Phosphoric Acid, Safety

Abstract: This safety assessment was required to complete the evaluation of a USQ for the storage and use of phosphoric acid in B Plant.

TRADEMARK DISCLAIMER. Reference herein to any specific comercial product, process, or service by trade name, trademark, manufacturer, or otherwise, does not necessarily constitute or imply its endorsement, recommendation, or favoring by the United States Government or any agency thereof or $i$ ts contractors or subcontractors.

Printed in the United States of America. To obtain copies of this document, contact: WHC/BCS Document Control Services, P.O. Box 1970, Mailstop H6-08, Rich tand WA 99352, Phone (509) 372-2420; Fax (509) 376-4989.
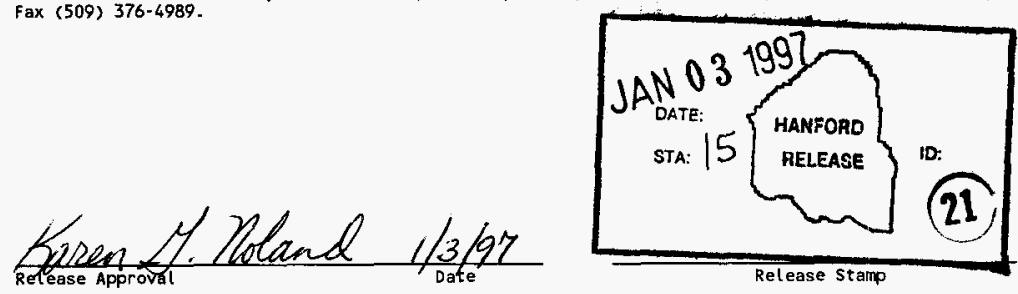

Approved for Public Release 
HNF-SD-WM-CN-086 REV 0

\section{SAFETY ASSESSMENT FOR STORAGE AND USE OF PHOSPHORIC ACID IN B PLANT}

Prepared By:

Los Alamos Technical Associates, Inc.

Richland, WA

For:

Fluor Daniel Hanford

Richland, WA

December 1996 
HNF-SD-WM-CN-086 REV 0

This page intentionally left blank. 


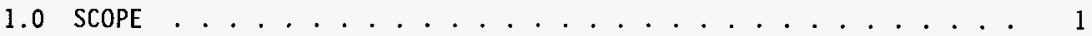

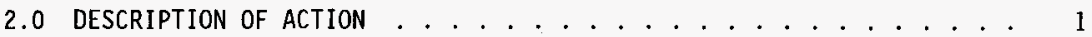

3.0 IDENTIFICATION OF HAZARDS ................ 2

4.0 HAZARDS ANALYSIS . . . . . . . . . . . . . . . 7

4.1 BASIC APPROACH . . . . . . . . . . . . . . . . . 7

5.0 CONSEQUENCE OF ACCIDENTS $\ldots \ldots \ldots \ldots$

5.1 CONSEQUENCE ANALYSIS METHODOLOGY ........... 7

5.1.1 Spill of Phosphoric During Delivery to B Plant . . . 9

5.1 .2 Massive Spill of Phosphoric Acid In AMU Area . . . . . 11

5.1.3 Slow Leak of Phosphoric Acid in AMU Area....... 13

5.1.4 Spray Release During Pumping Transfer From AMU Are
to Scale Tank . . . . . . . . 14

5.1.5 Failure of All Five Totes During a Major Sejsmic

5.1.6 Spray Leak of Phosphoric Acid Within Canyon Area . . 15

5.1.7 Releases During Storage In Operating Gallery... . . 17

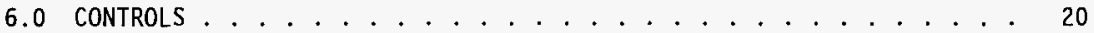

6.1 Floor Drains in AMU Area of $271-B \ldots 20$

6.2 Floor Drains in Operating Gallery ........... 20

6.3 Pipe Chase Deflectors . . . . . . . . . . . . 20

7.0 REFERENCES ......................... . . 21

$\begin{array}{ll}\text { APPENDIX A: } & \text { SPRAY MODEL RESULTS OF PHOSPHORIC SPRAY RELEASE FROM } \\ & \text { AMU AREA TO SCALE TANK AND WITHIN CANYON AREA ..... . A-1 }\end{array}$ 


\section{LIST OF TABLES}

Table 1. PHA Table for Phosphoric Acid Use USQ (2 Sheets). . . . . . . 5

Table 2. Risk Guidelines. . . . . . . . . . . . . . . . . . . . . . 7

Table 3. Site Boundary Distances Used in Offsite Dispersion

Table 4. Atmospheric Dispersion Coefficients $\left(x / Q s^{\circ}\right)^{\circ}$ Used in the

Accident Analysis. . . . . . 9

Table 5. Predicted Concentrations of Phosphoric Acid (Outside

Table 6. Predicted Concentrations of Phosphoric Acid (Massive * * . 11

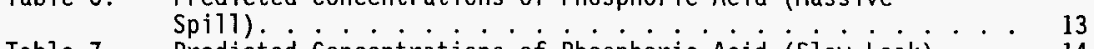

Table 7. Predicted Concentrations of Phosphoric Acid (Slow Leak). . 14

Table 8. Predicted Concentrations of Phosphoric Acid (Low-Pressure Spray Release). ...................... 15

Table 9. Predicted Concentrations of Phosphoric Acid (Seismic

Table 10. Predicted Concentrations of Phosphoric $\ldots \ldots$ Acid (Hi-Pressure Spray Release). . . . . . . . . . . . . 17

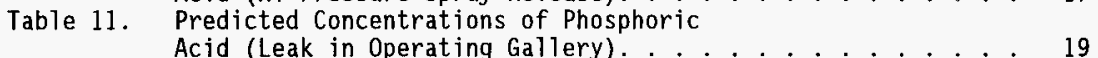

Table 12. Predicted Concentrations of Phosphoric
Acid (Seismic Event for Operating Gallery) . . . . . . . . 20 


\section{LIST OF TERMS}

$\begin{array}{ll}\text { ALARA } & \text { as low as reasonably achievable } \\ \text { AMU } & \text { aqueous make-up area } \\ \text { ARF } & \text { airborne release fraction } \\ \text { ARR } & \text { airborne release rate } \\ \text { BR } & \text { breathing rate } \\ \text { D\&D } & \text { decontamination and decommissioning } \\ \text { DOE-RL } & \text { U.S. Department of Energy-Richland Field office } \\ \text { ERPG } & \text { emergency response planning guideline } \\ \text { FDNW } & \text { Fluor Daniel Northwest } \\ \text { HNO } & \text { nitric acid } \\ \text { HEPA } & \text { high efficiency particulate air (filter) } \\ \mathrm{H}_{3} P 0_{4} & \text { phosphoric acid } \\ \text { ISB } & \text { interim safety basis } \\ \text { LLW } & \text { low level waste } \\ \mathrm{NaOH} & \text { sodium hydroxide } \\ \mathrm{NIOSH} & \text { National Institute for Occupational Safety and Health } \\ \mathrm{N}_{2} \mathrm{H}_{4} & \text { hydrazine } \\ \text { PHA } & \text { preliminary hazards analysis } \\ \text { PEL-TWA } & \text { permissible exposure limit - time weighted average } \\ \text { pSi } & \text { pounds per square inch } \\ \mathrm{RG} & \text { Risk Guideline } \\ \mathrm{SA} & \text { Safety Assessment } \\ \text { SSC } & \text { structure, system, and component } \\ \text { USQ } & \text { unreviewed safety question } \\ \text { WESF } & \text { Waste Encapsulation and Storage Facility } \\ \text { WHC } & \text { Westinghouse Hanford Company } \\ \mathrm{X} / Q & \text { atmospheric dispersion factor } \\ & \end{array}$


HNF-SD-WM-CN-086 REV 0

This page intentionally left blank. 
HNF-SD-WM-CN-086 REV 0

\section{SAFETY ASSESSMENT FOR STORAGE AND USE \\ OF PHOSPHORIC ACID IN B PLANT}

\subsection{SCOPE}

The last B Plant process mission was completed in 1985. The facility is currently undergoing preparations for transition to surveillance and maintenance (S\&M), pending final disposition. B Plant processed large quantities ( $>100 \mathrm{MC} i$ ) of ${ }^{137} \mathrm{Cs}$ and ${ }^{90} \mathrm{Sr}$. Residual radioactive contamination from this processing is located throughout the facility in various forms. There currently are significant quantities of radioactive contaminated organic solutions located in B Plant that are no longer required and need to be removed in preparation for S\&M. The organic liquid presents an unneeded combustible loading and was a major contributor to radiological releases analyzed in the B Plant Interim Safety Basis Accident Analysis (WHC 1996b). The organic liquid will be "washed" with phosphoric acid to transfer a large portion of the radionuclides to the phosphoric acid prior to the organic solution being removed from B Plant. An Unreviewed Safety Question (USQ) screening was conducted and it was determined that the liquid storage of phosphoric acid on the third floor of building 271-B (AMU area) or storage in the Operating Gallery, and the transfer of the acid to other B Plant locations for processing were not covered by the existing Safety Basis of B Plant. This Safety Assessment (SA) supports the USQ Evaluation and addresses the storage and use of phosphoric acid in $B$ Plant to reduce the radionuclide concentrations of the organic liquid. The transfer of the phosphoric acid with the radionuclides from the organic out of B Plant and to the Tank Farms is not in the scope of this Safety Assessment but is covered under existing safety documentation.

\subsection{DESCRIPTION OF ACTION}

The 76 wt\% phosphoric acid will be delivered in $1,249 \mathrm{~L}$ (330 gal) "tote" containers and it is planned to provide a total of five "tote" containers for the organic liquid "wash". The 330-gal totes will be delivered to the north side of the 271-B building and then moved via the service elevator to the third floor (AMU area) of the 271-B building. The five totes will then be stored adjacent to the north wall storage area of 271-B until used. Alternatively, the AMU area may not be used and the phosphoric acid could be transferred directly to the Operating Gallery and stored. In preparation for using the phosphoric acid, a $1 / 15 \mathrm{hp}$ pump will be used to pump the acid to a small scale tank (referred to as scale tank, as it sits upon scales to meter chemical solutions for processing) located on the 2nd floor of 271-B. The $1 / 15 \mathrm{hp}$ pump will deliver $8.7 \mathrm{psi}(60 \mathrm{kPa})$ of pressure (maximum) and the 2.5$\mathrm{cm}$ (1-in.) inner diameter braided tygon tubing with a wall thickness of $0.5-\mathrm{cm}$ (3/16-in.) will be used for the transfer to a small (75-gal) scale tank. When needed, the phosphoric acid in the small scale tank will be gravity fed (vertical distance of about $4.6-\mathrm{m}[15.1-\mathrm{ft}]$ ) through $5-\mathrm{cm}$ (2-in.) steel pipe (wall thickness of $0.4-\mathrm{cm}[0.154-i n$.$] ) to one of two organic storage tanks$ (TK-27-3 or TK-28-3) located in 211-B for initial neutralization. After initial neutralization of the residual $\mathrm{NaOH}$ in the organic, scale tank TK-26-B on the second floor will be used to gravity transfer the phosphoric acid to a 
canyon tank (TK-26-3). From TK-26-3, the phosphoric acid will be pumped to either TK-27-3 or TK-28-3 containing the organic and then agitated for several hours. After this wash, water will be added and the contents further agitated for a lesser period of time. The solution will be allowed to sit, allowing the heavier phosphoric acid now laden with radionuclides from the organic to settle to the bottom of the organic tank. After settling, the phosphoric acid and water will be decanted and transferred to TK-25-2 (or TK-26-1 or TK-30-3) for neutralization. This is repeated for two more cycles (total of three washes). After neutralization, the phosphoric acid will be transferred to TK24-1 (LLW tank). It will then eventually be transferred to the Tank Farms.

\subsection{IDENTIFICATION OF HAZARDS}

As the first step in the development of the Unreviewed Safety Evaluation for B Plant, a Preliminary Hazards Analysis (PHA) was performed. The analysis considered the qualitative hazards of the delivery and storage of the phosphoric acid to the third floor of $271-B$, and subsequent transfer and use in 221-B.

The analysis was structured around the form included as Table 1 . The first column, labelled "Process Step" defines the process step being analyzed. The second column, labelled "Hazardous Condition" refers to a credible abnormal event combined with an intrinsic hazard (radioactivity, toxic material, etc) which may result in adverse consequences to a facility worker and/or a person at a distance from the facility. The third column, "cause" lists abnormal events which may initiate the hazardous condition. The fourth column, "consequences", qualitatively describes the postulated consequences of the hazardous condition. The fifth and sixth columns list the engineered and administrative features expected to be included in the design and/or operating procedures which may prevent or mitigate the consequences of the hazardous condition. The lists of equipment and procedures in these columns can be used to demonstrate defense-in-depth, but are not taken into account in the assessment of the hazard. The lists can also be used as the basis of safety equipment lists and technical specifications. The column labelled "inventory", is a qualitative description of the hazardous material which could potentially be dispersed in the hazardous condition (e.g., phosphoric acid). The consequence and frequency category columns serve to qualitatively rank the safety consequences and frequencies of postulated accidents. The safety consequences are ranked in four categories:

So--No safety consequences or environmental events. Sl--Facility worker injury or exposure to hazardous materials; reportable release of hazardous materials within or near B Plant S2--Hazardous material exposure to person (co-located worker) at a distance from the $\mathrm{B} P \mathrm{Pl}$ ant; significant hazardous material discharge beyond the $B$ Plant

S3--Hazardous material exposure to the public; hazardous material discharge offsite 
The frequencies of the consequences (hazardous condition and failure of mitigative/preventive features) are ranked in four categories per WHC-CM-6-32, WP-4.6.:

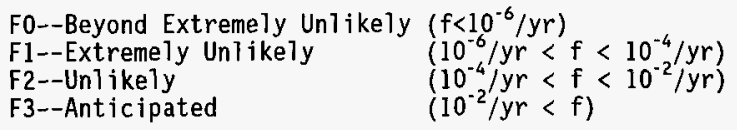

The information in the PHA table was used to select accidents for detailed analysis for this Safety Assessment, to help develop the accident scenarios, and to assist in the selection of safety-class and safetysignificant structures, systems and components (SSCS). The rationale used for deciding which accidents will require detail analysis is delineated in Section 4.0. 
HNF-SD-WM-CN-086 REV 0

This page intentionally left blank. 
Table 1. PHA Table for Phosphoric Acid Use USQ (2 Sheets).

\begin{tabular}{|c|c|c|c|c|c|c|c|c|c|}
\hline 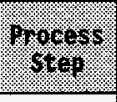 & Whang & k.t. & $8018 \%$ a $10 \%$ & 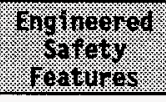 & 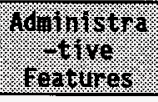 & (1) & onsog & fork & ingens \\
\hline $\begin{array}{l}\text { Acid } \\
\text { del ivery }\end{array}$ & $\begin{array}{l}\text { Spill during } \\
\text { offloading }\end{array}$ & $\begin{array}{l}\text { Human error or } \\
\text { mechanical } \\
\text { failure }\end{array}$ & $\begin{array}{l}\text { Worker burns; } \\
\text { inhalation of } \\
\text { respirable } \\
\text { droplets of } \\
\text { phosphoric acid }\end{array}$ & $\begin{array}{l}\text { Mechanical } \\
\text { strength of } \\
\text { forkl ift; } \\
\text { asphalt ramp } \\
\text { sloped that } \\
\text { al lows spills } \\
\text { to flow to } \\
\text { sewer drain } \\
\end{array}$ & $\begin{array}{l}\text { Forklift } \\
\text { operator } \\
\text { training }\end{array}$ & $\begin{array}{l}1,249 \mathrm{~L} \\
(330 \mathrm{gal}) \text { of } \\
\mathrm{H}_{3} \mathrm{PO}_{4}\end{array}$ & $\$ 2$ & $F 2$ & $\begin{array}{l}\text { Not considered } \\
\text { in ISB }\end{array}$ \\
\hline $\begin{array}{l}\text { Movement } \\
\text { of acid } \\
\text { via } \\
\text { elevator } \\
\text { to third } \\
\text { floor of } \\
271-B \text {, or } \\
\text { Operating } \\
\text { Gallery }\end{array}$ & $\begin{array}{l}\text { Spill during } \\
\text { el evator move- } \\
\text { ment }\end{array}$ & $\begin{array}{l}\text { Faulty } \\
\text { container }\end{array}$ & $\begin{array}{l}\text { Worker burns; } \\
\text { inhalation of } \\
\text { respirable } \\
\text { droplets of } \\
\text { phosphoric acid }\end{array}$ & & & $\begin{array}{l}1,249 \mathrm{~L} \\
(330 \mathrm{gal})\end{array}$ & s1 & F1 & $\begin{array}{l}\text { Same as above; } \\
\text { release rate } \\
\text { limited by small } \\
\text { area of elevator } \\
\text { shaft spill area }\end{array}$ \\
\hline $\begin{array}{l}\text { Transfer } \\
\text { by pallet } \\
\text { jack from } \\
\text { elevator } \\
\text { to storage } \\
\text { location } \\
\text { on 3rd } \\
\text { floor of } \\
\text { 271-B or } \\
\text { Operating } \\
\text { Gallery } \\
\end{array}$ & Spill of acid & $\begin{array}{l}\text { Human error by } \\
\text { inadvertently } \\
\text { bumping into } \\
\text { sharp object }\end{array}$ & $\begin{array}{l}\text { Worker burns; } \\
\text { inhalation of } \\
\text { respirable } \\
\text { droplets of } \\
\text { phosphoric acid }\end{array}$ & $\begin{array}{l}\text { Lift height of } \\
\text { pallet jack } \\
\text { limited such } \\
\text { that failure of } \\
\text { pallet jacket } \\
\text { resul ts in } \\
\text { small fall dis- } \\
\text { tance; floor } \\
\text { drains }\end{array}$ & $\begin{array}{l}\text { Operator } \\
\text { training }\end{array}$ & $\begin{array}{l}1,249 \mathrm{~L} \\
(330 \mathrm{gal})\end{array}$ & s1 & F2 & $\begin{array}{l}\text { Mot considered } \\
\text { in ISB }\end{array}$ \\
\hline $\begin{array}{l}\text { Leak dur- } \\
\text { ing } \\
\text { storage on } \\
3 \text { rd floor } \\
\text { of } 271-\mathrm{B} \\
\text { or } \\
\text { operating } \\
\text { Gallery }\end{array}$ & Spill of acid & $\begin{array}{l}\text { Container } \\
\text { accidently } \\
\text { punctured } \\
\text { Defect in con- } \\
\text { tainer } \\
\text { Major seismic } \\
\text { event }\end{array}$ & $\begin{array}{l}\text { Worker burns; } \\
\text { inhalation of } \\
\text { respirable } \\
\text { droplets of } \\
\text { phosphoric acid }\end{array}$ & $\begin{array}{l}\text { Floor drains; } \\
\text { Low center of } \\
\text { gravity } \\
\text { minimizes } \\
\text { tipping over }\end{array}$ & $\begin{array}{l}\text { Operator } \\
\text { training } \\
\text { Vendor QA }\end{array}$ & $\begin{array}{l}1,249 \mathrm{~L} \\
\text { (330 gat) } \\
1,249 \mathrm{~L} \\
\text { (330 gal ) } \\
6,245 \mathrm{~L} \\
(1,650 \mathrm{gal})\end{array}$ & $\begin{array}{l}\$ 2 \\
s 2 \\
s 2\end{array}$ & $\begin{array}{l}F 2 \\
F 2\end{array}$ & $\begin{array}{l}\text { Not considered } \\
\text { in ISB }\end{array}$ \\
\hline $\begin{array}{l}\text { Spill of } \\
\text { phosphoric } \\
\text { acid } \\
\text { mixing } \\
\text { with spill } \\
\text { of NaOH in } \\
271-\mathrm{B} \\
\end{array}$ & $\begin{array}{l}\text { Release of } \\
\text { respirabie } \\
\text { droplets of } \\
\text { acid }\end{array}$ & $\begin{array}{l}\text { Major seismic } \\
\text { event }\end{array}$ & $\begin{array}{l}\text { Worker burns; } \\
\text { generation of heat } \\
\text { and rel ease of } \\
\text { respirable } \\
\text { droplets of acid }\end{array}$ & $\begin{array}{l}\text { Low center of } \\
\text { gravity of } \\
\text { containers; } \\
\text { integrity of } \\
\text { containers }\end{array}$ & $\begin{array}{l}\text { Limits on } \\
\text { liquid } \\
\text { quantities }\end{array}$ & $\begin{array}{l}6,245 \mathrm{~L} \\
(1,650 \text { gat })\end{array}$ & s1 & F1 & $\begin{array}{l}\text { Event evaluated } \\
\text { in letter no. } \\
8 M 300-96-013 \\
\text { Note } 1\end{array}$ \\
\hline
\end{tabular}


Table 1. PHA Table for Phosphoric Acid Use USQ (2 Sheets).

\begin{tabular}{|c|c|c|c|c|c|c|c|c|c|}
\hline Woogs & 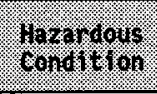 & 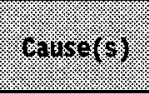 & 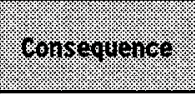 & 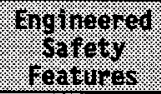 & 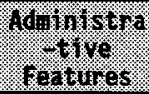 & 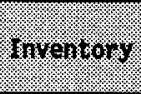 & 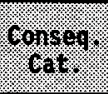 & mox & 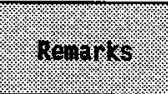 \\
\hline $\begin{array}{l}\text { Spray leak } \\
\text { during } \\
\text { pumping to } \\
\text { scale tank }\end{array}$ & $\begin{array}{l}\text { Release of } \\
\text { respirable } \\
\text { droplets of } \\
\text { acid }\end{array}$ & $\begin{array}{l}\text { Faul ty hose or } \\
\text { connection }\end{array}$ & $\begin{array}{l}\text { Inhalation of } \\
\text { respirable } \\
\text { droplets of } \\
\text { phosphoric acid }\end{array}$ & $\begin{array}{l}\text { Pressure rating } \\
\text { of hose, small } \\
\text { (1/15 hp) pump } \\
\text { motor providing } \\
\text { low pressure; } \\
\text { HEPA filters } \\
\text { for Operating } \\
\text { Gallery } \\
\end{array}$ & $\begin{array}{l}\text { operator } \\
\text { training, } \\
\text { visual } \\
\text { observation } \\
\text { during pumping }\end{array}$ & $\begin{array}{l}1,249 \mathrm{~L} \\
(330 \mathrm{gat})\end{array}$ & $s 2$ & F2 & $\begin{array}{l}\text { Spray leaks of } \\
\text { toxic materials } \\
\text { cons idered in } \\
\text { ISB, but does } \\
\text { not include } \\
\mathrm{H}_{3} \mathrm{PO}_{4} \text { * }\end{array}$ \\
\hline $\begin{array}{l}\text { Spray leak } \\
\text { during } \\
\text { gravity } \\
\text { transfer } \\
\text { to process } \\
\text { celi tank }\end{array}$ & $\begin{array}{l}\text { Release of } \\
\text { respirable } \\
\text { droplets of } \\
\text { acid }\end{array}$ & $\begin{array}{l}\text { Faulty pipe or } \\
\text { connection }\end{array}$ & $\begin{array}{l}\text { Release of } \\
\text { respirable } \\
\text { droplets of acid }\end{array}$ & $\begin{array}{l}5-\mathrm{cm}(2-\text { in. }) \\
\text { steel pipe, } \\
\text { scale tank area } \\
\text { exhausted } \\
\text { through HEPA } \\
\text { fitters }\end{array}$ & $\begin{array}{l}\text { operator } \\
\text { training }\end{array}$ & $\begin{array}{l}1,249 \mathrm{~L} \\
\text { (330 ga!) }\end{array}$ & s1 & F2 & $\begin{array}{l}\text { HEPA filters for } \\
\text { scale tank area; } \\
\text { canyon exhaust } \\
\text { system via HEPA } \\
\text { filters and } \\
\text { stack for spray } \\
\text { leak in canyon } \\
\text { cell area }\end{array}$ \\
\hline $\begin{array}{l}\text { Spray leak } \\
\text { during } \\
\text { pumping } \\
\text { operations } \\
\text { within } \\
\text { canyon } \\
\text { cell area } \\
\text { before } \\
\text { wash } \\
\end{array}$ & $\begin{array}{l}\text { Release of } \\
\text { respirable } \\
\text { droplets of } \\
\text { acid (toxic re- } \\
\text { lease) }\end{array}$ & $\begin{array}{l}\text { Faulty pipe or } \\
\text { connection }\end{array}$ & $\begin{array}{l}\text { Release of respir- } \\
\text { able droplets in } \\
\text { canyon area }\end{array}$ & $\begin{array}{l}\text { steel pipe, } \\
\text { canyon exhaust } \\
\text { system via HEPA } \\
\text { filters and } \\
\text { stack }\end{array}$ & $\begin{array}{l}\text { operator } \\
\text { training }\end{array}$ & $\begin{array}{l}1,249 \mathrm{~L} \\
(330 \mathrm{gal})\end{array}$ & s1 & 52 & $\star$ \\
\hline $\begin{array}{l}\text { Spray leak } \\
\text { during } \\
\text { pumping } \\
\text { operations } \\
\text { within } \\
\text { canyon } \\
\text { cell area } \\
\text { after wash }\end{array}$ & $\begin{array}{l}\text { Release of } \\
\text { respirable } \\
\text { droplets of } \\
\text { acid } \\
\text { (radiological } \\
\text { release) }\end{array}$ & $\begin{array}{l}\text { Faulty pipe or } \\
\text { connection }\end{array}$ & $\begin{array}{l}\text { Release of } \\
\text { respirable } \\
\text { droplets in canyon } \\
\text { area }\end{array}$ & $\begin{array}{l}\text { steel pipe, } \\
\text { canyon exhaust } \\
\text { system via HEPA } \\
\text { filters and } \\
\text { stack }\end{array}$ & $\begin{array}{l}\text { operator } \\
\text { training }\end{array}$ & $\begin{array}{l}1,249 \mathrm{~L} \\
(330 \mathrm{gal})\end{array}$ & s1 & F2 & $\begin{array}{l}\text { Covered under } \\
\text { existing ISB } \\
\text { (organic and } \\
\text { aqueous spray } \\
\text { releases) }\end{array}$ \\
\hline
\end{tabular}

Note:

* Further analyzed in this Safety Assessment

1 The concentrations of the $\mathrm{HNO}_{3}$ resulting from mixing of the $\mathrm{HNO}_{3}$ and $\mathrm{NaOH}$ in the ISB was not a function of total quantities of materials being mixed, but rather the rate of the chemical reaction resulting from the mixing". 


\subsection{HAZARDS ANALYSIS}

\subsection{BASIC APPROACH}

The basic approach of this Safety Assessment (SA) is to focus on the accidents that potentially produce the maximum consequences. Using the graded approach, little resources are spent initially on determining the frequency of the accidents, but rather they are assumed to be credible and the consequences are determined. If the consequences, even at a probability of one are acceptable, no further analys is is provided.

Accidents chosen for quantitative analysis focused upon those that potentially provided the highest phosphoric acid concentrations. The two types of scenarios identified that potentially provided high concentrations involved large spill areas and when the material was under pressure, such as during pumping operations. A review of the PHA table revealed that the most serious credible hazards with the potentially highest consequences were a spill of the entire contents of one tote outside the facility, the spill of one tote onto the floor of the AMU or Operating Gallery, the spill of all five totes during a seismic event, and spray releases during pumping of the acid. The risk guidelines, from WHC-CM-4-46 (WHC 1996a), are summarized in Table 2. This SA examines the potential accident scenarios to assure they do not exceed the risk guidelines of WHC-CM-4-46.

Table 2. Risk Guidelines.

\begin{tabular}{|c|c|c|c|c|}
\hline \multirow{2}{*}{ 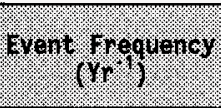 } & \multicolumn{2}{|c|}{ Toxis Giengerl concentration } & \multicolumn{2}{|c|}{ 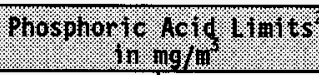 } \\
\hline & Onsite & Offsite & Onsite & Offsite \\
\hline$>10^{-2}$ to $\leq 10^{0}$ & ERPG-1 & PEL-TWA & 3 & 1 \\
\hline$>10^{-4}$ to $\leq 10^{-2}$ & ERPG-2 & ERPG-1 & 5 & 3 \\
\hline$>10^{-6}$ to $\leq 10^{-4}$ & ERPG-3 & ERPG-2 & 10,000 & 5 \\
\hline
\end{tabular}

1 From WHC-CM-4-46 (WHC 1996a)

2 From WSRC 1993

\subsection{CONSEQUENCE OF ACCIDENTS}

\subsection{CONSEQUENCE ANALYSIS METHODOLOGY}

$X / Q$ is the degree of atmospheric dispersion between the source term release point and a receptor location and can be characterized with an atmospheric dispersion coefficient, or $X / Q$ (where $X=$ airborne concentration at a given receptor, in $\mathrm{Ci} / \mathrm{m}^{3}$ or $\mathrm{mg} / \mathrm{m}^{3}$; and $Q=$ source term release rate, in $\mathrm{Ci} / \mathrm{s}$ or $\mathrm{mg} / \mathrm{s})$. The consequence analysis combines the results of the release rate and atmospheric dispersion to estimate concentrations to onsite and offsite individuals. For onsite calculations, $100-\mathrm{m}(328-\mathrm{ft})$ is used as the distance to the onsite receptor. For each of sixteen directions, a $99.5 \% \times / Q$ (meaning that the $X / Q$ is exceeded only $0.5 \%$ of the time) is calculated along with a $95 \%$ site-wide $X / Q$ (which considers all directions at the same time). The greatest of the seventeen values is selected as the onsite $X / Q$. The onsite $X / Q$ s are from WHC $1996 \mathrm{~b}$. 
For offsite calculations, the Hanford Site Boundary (i.e., fence line) is used as the location of the offsite receptor. The distances from $\mathrm{B} P \mathrm{Pl}$ ant to the Hanford Site Boundary are shown in Table 3 . The $95.5 \% X / Q$ values are compared for each of the sixteen directions with the greatest value selected as the offsite $X / Q$. The assumptions and calculations document, supporting Calculations and Assumptions for Use in WESF ISB, WHC-SD-WM-TI-733, Rev. 0 (Hey 1996) discusses a case where offsite distances correspond to the near side of the Columbia River (as opposed to the current Hanford Site boundary) for that stretch of the river which passes through the Hanford Site.

Potential consequences to a receptor at this nearer boundary are also considered for the accident evaluated. The offsite $X / Q$ s were performed for WESF, located immediately west of B Plant, and are valid for B Plant. The $X / Q$ values are derived by the GXQ code (Hey 1994). In all cases, the results are Peered Reviewed and then approved by the Hanford Environmental Dose Overview Pane1 (HEDOP).

Table 3. Site Boundary Distances Used in Offsite Dispersion Calculations.

\begin{tabular}{|c|c|c|}
\hline Transport otreetion & rence-1 I Ine or tatance & 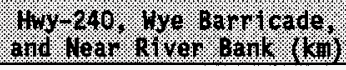 \\
\hline$s$ & 19.31 & 8.94 \\
\hline SSW & 16.64 & 8.26 \\
\hline SW & 18.08 & 8.26 \\
\hline WSW & 19.29 & 9.71 \\
\hline$W$ & 18.89 & 11.04 \\
\hline WNW & 19.39 & 14.36 \\
\hline $\mathrm{NW}$ & 19.81 & 11.49 \\
\hline NNW & 19.55 & 11.33 \\
\hline N & 22.78 & 12.99 \\
\hline NNE & 25.45 & 14.01 \\
\hline $\mathrm{NE}$ & 19.88 & 12.27 \\
\hline ENE & 17.04 & 12.14 \\
\hline$E$ & 16.87 & 13.65 \\
\hline ESE & 21.04 & 20.88 \\
\hline $\mathrm{SE}$ & 25.17 & 14.19 \\
\hline SSE & 21.08 & 11.71 \\
\hline
\end{tabular}

The toxic concentrations are determined using the relationship:

$$
\text { Conc. }\left(\mathrm{mg} / \mathrm{m}^{3}\right)=\text { release rate }(\mathrm{mg} / \mathrm{s}) \times X / Q\left(\mathrm{~s} / \mathrm{m}^{3}\right)
$$

Table 4 shows the onsite and offsite $X / Q$ values which are representative of the dispersion between the B Plant release point and the receptor locations under various release conditions. The particular $X / Q$ value used in an accident analysis is determined based on the physical phenomena associated with the accident. For toxicological releases, no credit for plume meander is taken, but since most postulated releases are from within the building, credit for building wake or the 211-B stack may normally be taken. 
Table 4. Atmospheric Dispersion Coefficients (X/Qs) Used in the Accident Analysis.

\begin{tabular}{|c|c|c|c|}
\hline 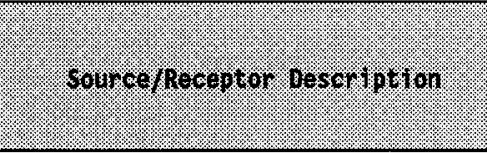 & 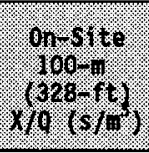 & 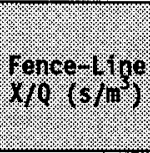 & 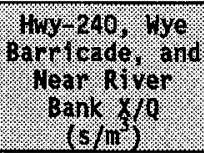 \\
\hline Ground level release, point source & $3.44 \mathrm{E}-02$ & $1.35 \mathrm{E}-05$ & $1.90 \mathrm{E}-05$ \\
\hline $\begin{array}{l}\text { Ground level release with building } \\
\text { wake }\end{array}$ & $1.15 \mathrm{E}-02$ & $1.34 \mathrm{E}-05$ & $1.88 E-05$ \\
\hline Stack release & $6.53 E-05^{1}$ & $8.89 E-06$ & $1.24 E-05^{2}$ \\
\hline
\end{tabular}

Notes:

1 Highest onsite $X / Q$ for a stack release is for a receptor $270 \mathrm{~m}$ (886 ft) west

2 Based upon ratio (1.4) of Hwy-240 to Fence-Line X/Qs for ground level releases for point source

\subsubsection{Spill of Phosphoric During Delivery to B Plant}

This scenario considers the consequences of the spilled contents of the phosphoric acid in a $1,249 \mathrm{~L}$ (330 gal) tote during offload upon delivery to $B$ Plant. It is anticipated that the totes will be removed by forklift or pallet jack from the rear of the delivery truck and placed onto a pallet jack and then transported by elevator to the third floor AMU area of building 271-B. The offloading area will be on an asphalt ramp that is sloped away (north) from 271-B. A curb north of the ramp then directs any runoff to the storm drain. A similar scenario was evaluated in WHC (1996b) for a $1,500-\mathrm{gal}, \mathrm{NaOH}$ spill and based upon the amount of slope and curb, a spill area of $93 \mathrm{~m}^{2}$ was calculated in the ISB. To calculate the concentration of the phosphoric acid spill 100-m offsite from the B Plant 271-B Building, the following are assumed.

- The tote contains $1,249 \mathrm{~L}$ (330 gal) of $76 \mathrm{wt} \% \mathrm{H}_{3} \mathrm{PO}_{4}$.

- The temperature for the acid of $20{ }^{\circ} \mathrm{C}$ is used, which simulates a warm day during the winter months.

- The wind is assumed to be $\sim 1 \mathrm{~m} / \mathrm{sec}$ with maximum $x / Q$ values used.

The methodology used refers to Clewell's report, A Simple Formula for Estimating Source Strengths from Spills of Toxic Liquid, ESL-TR-83-03 (Clewell 1983). The method is used for cases in which there is a spill of a volatile liquid and is the same model used in the ISB for $\mathrm{NaOH}$ and $\mathrm{HNO}_{3}$. $\mathrm{H}_{3} \mathrm{PO}_{4}$ solutions are not very volatile, having low vapor pressures. The formula used to estimate the source strength is

$$
Q=0.08 \times U^{\frac{3}{4}} \times A \times\left(1+\left[4.3 \times 10^{-3} \times \mathrm{Tp}^{2}\right]\right) \times \mathrm{Z}
$$


where

$$
\begin{aligned}
Q & =\text { source strength in } \mathrm{kg} / \text { hour } \\
U & =\text { wind velocity in } \mathrm{m} / \mathrm{sec} \\
A & =\text { spill area in } \mathrm{m}^{2} \\
\mathrm{TP} & =\text { pool temperature }{ }^{\circ} \mathrm{C} \\
Z & =\text { volatility factor in relation to hydrazine, dimensionless. }
\end{aligned}
$$

Note: Hydrazine is not present at B Plant. Clewe 11 's equation uses it as a standard by which the volatility of other compounds are measured.

The vapor pressure of $\mathrm{H}_{3} \mathrm{PO}_{4}$ at $20{ }^{\circ} \mathrm{C}$ is $0.03 \mathrm{~mm} \mathrm{Hg}$ (NIOSH 1990).

The volatility factor of $Z$ (from Clewell 1983) is found by

$$
\mathrm{z}=\mathrm{Pvb} \times \frac{\mathrm{Mb}}{\mathrm{Pvh} \times \mathrm{Mh}}
$$

where

$$
\begin{aligned}
\text { Pvb } & =\text { vapor pressure of } \mathrm{H}_{3} \mathrm{PO}_{4}=0.03 \mathrm{~mm} \mathrm{Hg} \\
\text { Pvh } & =\text { vapor pressure of hydrazine at } 20{ }^{\circ} \mathrm{C}=10.0 \mathrm{~mm} \mathrm{Hg} \text { (NIOSH 1990) } \\
M b & =\text { molecular weight of } \mathrm{H}_{3} \mathrm{PO}_{4}=98.0 \\
M h & =\text { molecular weight of hydrazine }\left(\mathrm{N}_{2} \mathrm{H}_{4}\right)=32.1
\end{aligned}
$$

Solving for $Z$ yields 0.00916 .

The spill area is estimated based upon the ISB value of $93 \mathrm{~m}^{2}$.

$$
\begin{aligned}
A & =93 \mathrm{~m}^{2} \\
U & =\text { assume } 1(\mathrm{~m} / \mathrm{sec}) \text { wind velocity } \\
\mathrm{Tp} & =20{ }^{\circ} \mathrm{C} \\
\text { Qcalc } & =0.08 \times \mathrm{U}^{\frac{3}{4}} \times \mathrm{A} \times\left[1+\left(4.3 \times 10^{-3} \times \mathrm{Tp}^{2}\right)\right] \times \mathrm{Z} \\
\text { Qcalc } & =0.185 \mathrm{~kg} / \mathrm{h}=51.4 \mathrm{mg} / \mathrm{sec}
\end{aligned}
$$

As the spill is outside the facility, no credit is taken for building wake and the onsite concentration, at $100 \mathrm{~m}$, is calculated as:

$$
\text { Conc. } \begin{aligned}
\left(\mathrm{mg} / \mathrm{m}^{3}\right)=\text { release rate }(\mathrm{mg} / \mathrm{s}) \times \times / Q\left(\mathrm{~s} / \mathrm{m}^{3}\right) \\
=51.4 \mathrm{mg} / \mathrm{s} \times 3.44 \mathrm{E}-02 \mathrm{~s} / \mathrm{m}^{3}=1.77 \mathrm{mg} / \mathrm{m}^{3}
\end{aligned}
$$

It should be noted that the equation from Clewell (1983) is empirical and therefore not dimensionally consistent. The value for $U$ of $1 \mathrm{~m} / \mathrm{sec}$ results in the largest concentration because it varies as $U^{0.75}$ and $X / Q$ varies as $1 / U$. At a $2 \mathrm{~m} / \mathrm{sec}$ wind the ratio of $U^{0.75} / U$ is 0.84 and at $5 \mathrm{~m} / \mathrm{sec}$ the ratio is 0.67 , where at $1 \mathrm{~m} / \mathrm{sec}$ it is 1.0 ; therefore, the onsite and offsite concentrations çalculated above are worst-case values and are $1.78 \mathrm{mg} / \mathrm{m}^{3}$ and $6.98 \times 10^{-4} \mathrm{mg} / \mathrm{m}^{3}$. 
Table 5. Predicted Concentrations of Phosphoric Acid (Outside Spill).

\begin{tabular}{|c|c|c|c|}
\hline Recepgor. & . & Hopo pringe cone. & (c) \\
\hline Onsite & $3.44 \quad E-02$ & 1.77 & 3 \\
\hline Offsite & $1.35 \mathrm{E}-0.5$ & 0.0007 & 1 \\
\hline
\end{tabular}

Note:

$R G=$ risk guideline for $>10^{-2}$ to $\leq 10^{\circ}$.

By comparison, the maximum concentration at the alternate site boundary described in Section 5.1 , which considers Highway 240 and the near side of the river, is $0.001 \mathrm{mg} / \mathrm{m}^{3}$.

\subsubsection{Massive Spill of Phosphoric Acid In AMU Area}

This scenario considers a massive leak from a tote containing its capacity of $1,249 \mathrm{~L}(330 \mathrm{gal})$ of $76 \mathrm{wt} \%$ phosphoric acid such that the entire contents are quickly released to the concrete floor of the 3rd floor AMU area. To calculate the concentration of the phosphoric acid spill 100-m offsite from the B Plant 271-B Building, the following are assumed.

- The tote contains $1,249 \mathrm{~L}(330 \mathrm{gal})$ of $76 \mathrm{wt} \% \mathrm{H}_{3} \mathrm{PO}_{4}$.

- The temperature for the acid of $25{ }^{\circ} \mathrm{C}$ is used, which simulates a typical day inside the AMU area during winter.

- The airflow is assumed to be $1 \mathrm{~m} / \mathrm{sec}$ with maximum $x / Q$ values (taking credit for building wake).

The same methodology as above (outside the facility) is used for the spill inside the AMU area.

The vapor pressure of $\mathrm{H}_{3} \mathrm{PO}_{4}$ at $25{ }^{\circ} \mathrm{C}$ is $0.05 \mathrm{~mm} \mathrm{Hg}$ (Kirk-0thmer 1978).

The volatility factor of $Z$ is found by

$$
\mathrm{Z}=\mathrm{Pvb} \times \frac{\mathrm{Mb}}{\mathrm{Pvh} \times \mathrm{Mh}}
$$

where

$$
\begin{aligned}
\mathrm{Pvb} & =\text { vapor pressure of } \mathrm{H}_{3} \mathrm{PO}_{4}=0.05 \mathrm{~mm} \mathrm{Hg} \\
\mathrm{Pvh} & =\text { vapor pressure of hydrazine at } 25{ }^{\circ} \mathrm{C}=19.3 \mathrm{~mm} \mathrm{Hg} \text { (Perry 1984) } \\
\mathrm{Mb} & =\text { molecular weight of } \mathrm{H}_{3} \mathrm{PO}_{4}=98.0 \\
\mathrm{Mh} & =\text { molecular weight of hydrazine }\left(\mathrm{N}_{2} \mathrm{H}_{4}\right)=32.1
\end{aligned}
$$

Solving for $Z$ yields 0.0079 .

The floor area of the third floor AMU is such that the center of the room along the E-W direction is slightly elevated with a slope toward floor drains located toward the north and south walls. Similarly, the floor is 
sloped from the north and south walls, sloping down to the drains located approximately half the distance to the mid E-W elevated axis. The spill will flow downslope from the north wall toward the $10-\mathrm{cm}$ (4-in.) diameter floor drains (3, located approximately 7.3-m (24-ft) apart, 2.7-m (9-ft) from the north wall, and 3, located approximately $7.3-\mathrm{m}(24-\mathrm{ft})$ apart, $2.7-\mathrm{m}(9-\mathrm{ft})$ from the south wall) that lead to the chemical sewer line which leads to the 211BA neutralization system. The spill area is $714 \mathrm{~m}^{2}$ (total floor area of third floor of building 271-B), minus the area of a bermed area $\left(24 \mathrm{~m}^{2}\right)$ surrounding the chemical makeup tanks, and the walled-off office area (24.4 $\mathrm{m}^{2}$ ). The walled-off office area has doors leading to each of the offices, and spilled liquid could flow into this area under the doors. It is assumed that approximately half the office floor area would contain phosphoric acid from the spill. Therefore, the total area for the spill is $714 \mathrm{~m}^{2}-24 \mathrm{~m}^{2}-12.2$ $\mathrm{m}^{2}=678 \mathrm{~m}^{2}$. The $1 \mathrm{iquid}$ depth would be only approximately $0.2-\mathrm{cm}(0.08-\mathrm{in}$.), and shows that the assumption that the spill area is indeed as large as $678 \mathrm{~m}^{2}$ is very conservative.

$$
\begin{aligned}
A & =678 \mathrm{~m}^{2} \\
U & =\text { assume } 1(\mathrm{~m} / \mathrm{sec}) \text { air flow } \\
T p & =25{ }^{\circ} \mathrm{C} \\
\text { Qcalc } & =0.08 \times U^{\frac{3}{4}} \times A \times\left[1+\left(4.3 \times 10^{-3} \times T p^{2}\right)\right] \times Z \\
\text { Qcalc } & =1.58 \mathrm{~kg} / \mathrm{h}=439 \mathrm{mg} / \mathrm{sec}
\end{aligned}
$$

Since the spill occurs inside the facility, credit for building wake is taken and the onsite concentration, at $100 \mathrm{~m}$, is calculated as:

$$
\text { Conc. } \begin{aligned}
& \left(\mathrm{mg} / \mathrm{m}^{3}\right)=\text { release rate }(\mathrm{mg} / \mathrm{s}) \times X / Q\left(\mathrm{~s} / \mathrm{m}^{3}\right) \\
= & 439 \mathrm{mg} / \mathrm{s} \times 1.15 \mathrm{E}-02 \mathrm{~s} / \mathrm{m}^{3}=5.05 \mathrm{mg} / \mathrm{m}^{3}
\end{aligned}
$$

This concentration will only last for a short period of time, as the six nearest floor drains will rapidly allow the liquid to drain to the chemical sewer. With six 10-cm (4-in.) floor drains, the time to drain the liquid from the floor is estimated to take 1-min or less, and therefore the release is taken to be for only 1-min. The 1-min estimate is based upon the following. The floor is sloped to the floor drains and assuming a conservative estimate of $0.5 \%$ slope (normal slope to drains are $2 \%$ ) and a distance of $37.80-\mathrm{m}$ (124.02-ft) from the farthest spill perimeter to a floor drain, the head of the 1 jquid is $18.9 \mathrm{~cm}(7.44 \mathrm{in.})$. Using the relationship of: velocity = $(2 \mathrm{gh})^{1 / 2}$ and a head of $18.9 \mathrm{~cm}(7.44 \mathrm{in.})$, the velocity of the liquid flowing to the floor drain is approximately $190 \mathrm{~cm} / \mathrm{sec}(74.8 \mathrm{in} . / \mathrm{sec})$. The time for the spilled liquid to flow the farthest distance to a floor drain is therefore approximately 20 seconds, and is rounded up to be 1 minute.

The floor drains are adequate to allow a rapid discharge of the spilled acid to the chemical sewer, as the vertical distance from the 3rd floor of the AMU area to the chemical sewer is approximately $9 \mathrm{~m}$. This provides a head such that the discharge velocity down the $10-\mathrm{cm}$ (4-in.) drain is approximately: $(2 \mathrm{gh})^{\mathrm{g}}=\left(2 \times 980 \mathrm{~cm} / \mathrm{s}^{2} \times 900 \mathrm{~cm}\right)^{1 / 2}=1,328 \mathrm{~cm} / \mathrm{s}$. With a cross-sectional area of $81.7 \mathrm{~cm}^{2}\left(12.66 \mathrm{in}^{2}\right)$ and a velocity of $1,328 \mathrm{~cm} / \mathrm{s}(523$ in./s), the flow rate down the $10-\mathrm{cm}(4-i n$.$) pipe is 1.1 \mathrm{E}+05 \mathrm{~cm}^{3} / \mathrm{s}$ or $110 \mathrm{~L} / \mathrm{s}$. With $1,249 \mathrm{~L}(330 \mathrm{ga})$ of phosphoric acid, the time to drain this amount through a single drain is $11.4 \mathrm{~s}$. With about $50 \%$ of the available drain area being occupied by the drain strainer, the time to drain $1,249 \mathrm{~L}$ (330 gal) through a single drain is approximately doubled, or $23 \mathrm{~s}$. 
Therefore, it is concluded that the drains provide adequate drainage to preclude backing up of the drainage from the floor.

WHC-CM-4-46 allows the calculation for comparison with the guidelines as the peak 15-minute average concentration for a chemical where the toxic effect is immediate (i.e., concentration-dependent). Therefore, the 15-minute average is $1 / 15$ the value above $\left(5.05 \mathrm{mg} / \mathrm{m}^{3}\right)$, or $0.34 \mathrm{mg} / \mathrm{m}^{3}$. The resulting onsite and offsite concentrations are shown in Table 6 .

Table 6. Predicted Concentrations of Phosphoric Acid (Massive Spill).

\begin{tabular}{|c|c|c|c|}
\hline 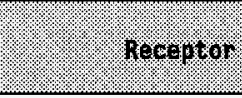 & 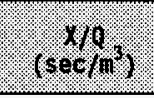 & 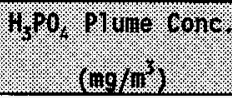 & $\mathrm{gB} \cdot(109711)$ \\
\hline Onsite & $1.15 \mathrm{E}-02$ & 0.34 & 3 \\
\hline Offsite & $1.34 \mathrm{E}-05$ & 0.0004 & 1 \\
\hline
\end{tabular}

Note: $R G=$ risk guideline for $>10^{-2}$ to $\leq 10^{\circ}$.

By comparison, the maximum concentration at the alternate site boundary described in Section 5.1, which considers Highway 240 and the near side of the river, is $0.0006 \mathrm{mg} / \mathrm{m}^{3}$.

\subsubsection{Slow Leak of Phosphoric Acid in AMU Area}

An additional scenario is one in which a small leak develops in a tote, such that the entire $1,249 \mathrm{~L}(330 \mathrm{gal})$ is spilled over a 15 -min period. This is examined as it does not allow averaging the concentration over a 15-min period and the resulting concentration from the vaporization is such that it is constant for the entire $15-$ min period. The spill rate, assuming the entire $1,249 \mathrm{~L}(330 \mathrm{gal})$ is spilled over a 15 -min period is therefore $1.39 \mathrm{~L} / \mathrm{s}$. The spill area will be less than the massive spill, but the concentration resulting will occur for 15-min. The approximate distance from a tote to a floor drain is $3-\mathrm{m}(10-\mathrm{ft})$ and with a floor slope of $0.5 \%$, the effective head for the distance between the tote and floor drain is $1.5-\mathrm{cm}(0.6-\mathrm{in}$.). The flow velocity is approximated as: velocity $=(2 \mathrm{gh})^{1 / 2}$, or $54.2 \mathrm{~cm} / \mathrm{s}$ $(21.3 \mathrm{in.} / \mathrm{s})$. The time for the spilled liquid to flow to the drain is therefore $300 \mathrm{~cm} \div 54.2 \mathrm{~cm} / \mathrm{s}=5.5 \mathrm{~s}$. In 5.5 seconds, the total volume of liquid spilled is $7.6 \mathrm{~L}(2.0 \mathrm{gal})$ and using the same conservative spill depth of $0.2 \mathrm{~cm}(0.08 \mathrm{in}$.$) , the spill area is 3.8 \mathrm{E}+04 \mathrm{~cm}^{2}\left(3.8 \mathrm{~m}^{2}\right)$. Using the relationship above of:

$$
\begin{aligned}
A & =3.8 \mathrm{~m}^{2} \\
Z & =0.0079 \\
U & =\text { assume } 1(\mathrm{~m} / \mathrm{sec}) \text { air flow } \\
T p & =25{ }^{\circ} \mathrm{C} \\
\text { Qcalc } & =0.08 \times \mathrm{U}^{\frac{3}{4}} \times A \times\left[1+\left(4.3 \times 10^{-3} \times \mathrm{Tp}^{2}\right)\right] \times \mathrm{Z} \\
\text { Qcalc } & =0.0089 \mathrm{~kg} / \mathrm{h}=2.46 \mathrm{mg} / \mathrm{sec}
\end{aligned}
$$


The onsite concentration, at $100 \mathrm{~m}(328 \mathrm{ft})$, is calculated as:

$$
\begin{gathered}
\text { Conc. }\left(\mathrm{mg} / \mathrm{m}^{3}\right)=\text { release rate }(\mathrm{mg} / \mathrm{s}) \times \times / Q\left(\mathrm{~s} / \mathrm{m}^{3}\right) \\
=2.46 \mathrm{mg} / \mathrm{s} \times 1.15 \mathrm{E}-02 \mathrm{~s} / \mathrm{m}^{3}=0.028 \mathrm{mg} / \mathrm{m}^{3}
\end{gathered}
$$

The offsite concentration at the Fence-Line is calculated as:

$$
\begin{gathered}
\text { Conc. }\left(\mathrm{mg} / \mathrm{m}^{3}\right)=\text { release rate }(\mathrm{mg} / \mathrm{s}) \times X / Q\left(\mathrm{~s} / \mathrm{m}^{3}\right) \\
=2.46 \mathrm{mg} / \mathrm{s} \times 1.34 \mathrm{E}-05 \mathrm{~s} / \mathrm{m}^{3}=0.00003 \mathrm{mg} / \mathrm{m}^{3}
\end{gathered}
$$

\begin{tabular}{|c|c|c|c|}
\hline mecoptor & $\left.(\operatorname{soc} /)_{1}\right)$ & 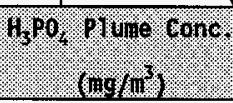 & (2) \\
\hline Onsite & $1.15 \mathrm{E}-02$ & 0.028 & 3 \\
\hline offsite & $1.34 E-05$ & 0.00003 & 1 \\
\hline
\end{tabular}

The onsite and offsite consequences are summarized in Table 7.

Table 7. Predicted Concentrations of Phosphoric Acid (Slow Leak).

Note:

$$
\mathrm{RG}=\text { risk guideline for }>10^{-2} \text { to } \leq 10^{\circ} \text {. }
$$

By comparison, the maximum concentration at the alternate site boundary described in Section 5,1 , which considers Highway 240 and the near side of the river, is $0.00005 \mathrm{mg} / \mathrm{m}^{3}$.

\subsubsection{Spray Release During Pumping Transfer From AMU Area to Scale Tank}

A spray leak could occur during transfer of the phosphoric acid from the third floor of 271-B (AMU area) to the scale tanks located on the second floor. A $1 / 15 \mathrm{hp}$ motor will be used to pump the acid from the totes to the second floor scale tanks. The tubing will be braided tygon, 2.5-cm (1-in.) inner diameter, wall thickness of $0.5-\mathrm{cm}(3 / 16-i n$.$) , and rated for 400 \mathrm{psi}$ $(2,758 \mathrm{kPa})$ at $73{ }^{\circ} \mathrm{F}$. The density of the $76 \mathrm{wt} \%$ phosphoric acid at $25{ }^{\circ} \mathrm{C}$ is $1.573 \mathrm{~g} / \mathrm{cm}^{3}$ and a viscosity of $13.725 \mathrm{cP}$ (Kirk-0thmer 1978).

The spray release is modeled using $A$ Model for Predicting Respirable Releases from Pressurized Leaks, WHC-SD-GN-SWD-20007 (WHC 1994). This conservative spray model requires certain input parameters be provided, such as slit length, slit depth, pressure, liquid density and viscosity, and certain slit characteristics. The slit length is assumed to be approximately the outer diameter of the tubing $(\sim 3.1-\mathrm{cm}[\sim 1.2-\mathrm{in.}])$ and the slit depth is the tubing wall thickness $(0.48-\mathrm{cm}[0.1875-\mathrm{in}]$.$) . The model then determines$ the optimum slit width that maximizes the respirable leak rate and determines the respirable leak rate and total leak rate. An assumed particle size of 20 $\mu \mathrm{m}$ is used for this analysis, which allows evaporation of the liquid droplet down to $10 \mu \mathrm{m}$ while enroute to receptors. Appendix A provides the output file for the spray release and the respirable leak rate is $1.15 \mathrm{E}-03 \mathrm{~g} / \mathrm{s}$ (1.15 $\mathrm{mg} / \mathrm{s})$. The assumed slit width and shape of the slit calculated to maximize the respirable leak rate by the spray model is very conservative in this case, as the flexible hose is modeled as a tube with a perfectly rectangular si it 
shape. For a flexible hose, the actual slit shape would be more of an oblong oval, resulting in a considerably less respirable leak rate than that

modelled. With $76 \mathrm{wt} \%$ being phosphoric acid, the respirable leak rate is approximately $0.874 \mathrm{mg} / \mathrm{s}$ for the phosphoric acid. Taking credit for building wake, the onsite concentration, at $100 \mathrm{~m}$, is calculated as:

$$
\begin{gathered}
\text { Conc. }\left(\mathrm{mg} / \mathrm{m}^{3}\right)=\text { release rate }(\mathrm{mg} / \mathrm{s}) \times \times / Q\left(\mathrm{~s} / \mathrm{m}^{3}\right) \\
=0.874 \mathrm{mg} / \mathrm{s} \times 1.15 \mathrm{E}-02 \mathrm{~s} / \mathrm{m}^{3}=0.01 \mathrm{mg} / \mathrm{m}^{3}
\end{gathered}
$$

The onsite and offsite doses are summarized in Table 8 .

Table 8. Predicted Concentrations of Phosphoric Acid (Low-Pressure Spray

\begin{tabular}{|c|c|c|c|}
\hline recropor & $.6 \sec ^{2}$ & Her. & $.76 \cdot(1997 \%$ \\
\hline Onsite & $1.15 \mathrm{E}-02$ & 0.01 & 3 \\
\hline Offsite & $1.34 E-05$ & $1.2 \mathrm{E}-05$ & 1 \\
\hline
\end{tabular}
Release).

Note:

$R G=$ risk guideline for $>10^{-2}$ to $\leq 10^{\circ}$.

By comparison, the maximum concentration at the alternate site boundary described in Section 5.1, which considers Highway 240 and the near side of the river, is $1.64 \mathrm{E}-05 \mathrm{mg} / \mathrm{m}^{3}$.

\subsubsection{Failure of A11 Five Totes In AMU Area During a Major Seismic Event}

The phosphoric acid will be stored in B Plant for a maximum of 2 months before use. This scenario considers a seismic event of such magnitude that cracks in the 271-B building occur and portions of the roof fall, impacting the five totes and all liquid spill onto the AMU area floor. It is further assumed that debris from the ceiling block the floor drains such that the resulting concentration that occurs from the vaporization of the acid continues for more than 15 minutes. The annual frequency of the seismic event is estimated as $<1 \mathrm{E}-03$, which is based upon the probability of an earthquake at B Plant exerting a horizontal acceleration of slightly greater than $0.12 \mathrm{~g}$ (WHC 1996b). With the phosphoric acid being stored for a maximum of 2 months, the overall frequency is estimated as 1.67 E-04. As earlier discussed, the total AMU floor is $714 \mathrm{~m}^{2}$ with $24 \mathrm{~m}^{2}$ having a berm around the chemical make-up tanks. Since a considerably larger quantity of acid is spilled then that analyzed in the single tote spill, the resultant spill area is estimated. Although the initial spill area may initially approach the total floor area of the AMU ( $\left.714 \mathrm{~m}^{2}-24 \mathrm{~m}^{2}=690 \mathrm{~m}^{2}\right)$, the spilled acid will drain back toward the drains. To calculate the final spill area with the drains blocked by debris, the floor is modelled as a single cone with one floor drain at the apex of the cone. The volume of a cone is $(\pi \backslash 3)\left(r^{2}\right)(h)$, where $r$ is the radius and $h$ is the height. With a slope of $0.5 \%, h=.005 \mathrm{r}$. The volume of the spilled acid is $6,245 \mathrm{~L}(1,650 \mathrm{ga})$ and solving for $r$, the spill radius becomes $10.77 \mathrm{~m}$. With a radius of $10.77 \mathrm{~m}$, the spill area is $\pi \mathrm{r}^{2}=364.4 \mathrm{~m}^{2}$. Except for the difference in area, the same parameters (volatility factor, temperature, etc.) apply from Section 5.1.2. 


$$
\begin{aligned}
A & =364.4 \mathrm{~m}^{2} \\
U & =\text { assume } 1(\mathrm{~m} / \mathrm{sec}) \text { air flow } \\
T p & =25{ }^{\circ} \mathrm{C} \\
\text { Qcalc } & =0.08 \times \mathrm{U}^{\frac{3}{4}} \times \mathrm{A} \times\left[1+\left(4.3 \times 10^{-3} \times \mathrm{Tp}^{2}\right)\right] \times \mathrm{Z} \\
\text { Qcalc } & =0.849 \mathrm{~kg} / \mathrm{h}=235.8 \mathrm{mg} / \mathrm{sec}
\end{aligned}
$$

Since the spill occurs inside the facility (but with potentially additional leak paths), credit for building wake is taken and the onsite

\begin{tabular}{|c|c|c|c|}
\hline . & 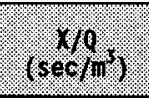 & Mpo. paluse conic & 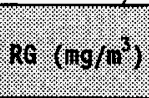 \\
\hline Onsite & $1.15 E-02$ & 2.71 & 5 \\
\hline Offsite & $1.34 \mathrm{E}-05$ & 0.0032 & 3 \\
\hline
\end{tabular}

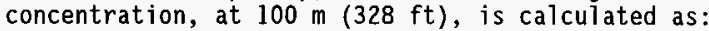

$$
\begin{gathered}
\text { Conc. }\left(\mathrm{mg} / \mathrm{m}^{3}\right)=\text { release rate }(\mathrm{mg} / \mathrm{s}) \times \times / Q\left(\mathrm{~s} / \mathrm{m}^{3}\right) \\
=235.8 \mathrm{mg} / \mathrm{s} \times 1.15 \mathrm{E}-02 \mathrm{~s} / \mathrm{m}^{3}=2.71 \mathrm{mg} / \mathrm{m}^{3}
\end{gathered}
$$

The onsite and offsite doses are summarized in Table 9.

Table 9. Predicted Concentrations of Phosphoric Acid (Seismic Event).

Note:

$$
R G=\text { risk guidel ine for }>10^{-4} \text { to } \leq 10^{-02} \text {. }
$$

By comparison, the maximum concentration at the alternate site boundary described in Section 5.1 , which considers Highway 240 and the near side of the river, is $0.0044 \mathrm{mg} / \mathrm{m}^{3}$.

\subsubsection{Spray Leak of Phosphoric Acid Within Canyon Area}

Inter-tank transfers within the 221-B canyon area are to be made and $5-\mathrm{cm}(2-i \mathrm{n}$.$) steel pipe and 100 \mathrm{psi}(690 \mathrm{kPa})$ pressure are normally used.

This accident scenario considers a toxic release of phosphoric acid during one of the high-pressure transfers. The same spray model is used but with $5-\mathrm{cm}$ (2-in.) pipe with a wall thickness of $0.4-\mathrm{cm}(0.154-i n$.$) . The leak is assumed$ to result from a $5-\mathrm{cm}$ (2-in.) slit in the pipe or flange gasket. The spray model output file is provided in Appendix $A$ and results in a respirable leak rate of $4.58 \mathrm{E}-01 \mathrm{~g} / \mathrm{s}$. Since the phosphoric acid is $76 \mathrm{wt} \%$, the respirable leak rate of the phosphoric acid is effectively $3.48 \mathrm{E}-01 \mathrm{~g} / \mathrm{s}$ (348 $\mathrm{mg} / \mathrm{s})$. Taking credit for a stack release, the onsite concentration is calculated as:

$$
\text { Conc. } \begin{aligned}
&\left(\mathrm{mg} / \mathrm{m}^{3}\right)= \text { release rate }(\mathrm{mg} / \mathrm{s}) \times \times / Q\left(\mathrm{~s} / \mathrm{m}^{3}\right) \\
&=348 \mathrm{mg} / \mathrm{s} \times 6.53 \mathrm{E}-05 \mathrm{~s} / \mathrm{m}^{3}=0.023 \mathrm{mg} / \mathrm{m}^{3}
\end{aligned}
$$

The onsite and offsite doses are summarized in Table 10. 
Table 10. Predicted Concentrations of Phosphoric Acid (Hi-Pressure Spray Release).

\begin{tabular}{|c|c|c|c|}
\hline (3) & $(\sec )$ & Hop ploine Gonc. & git $(\log 10$ \\
\hline $\begin{array}{l}\text { Onsite }(270 \mathrm{~m}[886 \mathrm{ft}] \\
\text { west) }\end{array}$ & $6.53 \mathrm{E}-05$ & 0.023 & 3 \\
\hline Offsite & $8.89 \mathrm{E}-06$ & 0.0031 & 1 \\
\hline
\end{tabular}

Note:

$\mathrm{RG}=$ risk guideline for $>10^{-2}$ to $\leq 10^{\circ}$.

By comparison, the maximum concentration at the alternate site boundary described in Section 5.1, which considers Highway 240 and the near side of the river, is $0.0043 \mathrm{mg} / \mathrm{m}^{3}$.

\subsubsection{Releases During Storage In Operating Gallery}

The phosphoric totes may not be stored in the 271-B AMU area but could be delivered via the second floor of 271-B directly to the Operating Gallery and stored. The following sections address storage of the acid in the Operating Gallery. If stored in the Operating Gallery, the same 1/15 hp pump and flexible hose will be used for the transfer of the acid from the totes to the scale tanks. For any spray release that might occur, the previous analysis for the AMU area bound the consequences that would occur if transferred from the Operating Gallery. The Operating Gallery air circulation system is provided with HEPA filters that would even further mitigate the consequences for a spray release. The Operating Gallery is $4.3-\mathrm{m}$ (14-ft) wide, $3.7-\mathrm{m}(12-\mathrm{ft}) \mathrm{high}$ and extends approximately $220-\mathrm{m}_{3}(800-\mathrm{ft})$ adjacent to the 221-B canyon area. Ten exhaust fans, rated at $142 \mathrm{~m}^{3} / \mathrm{min}(5,000 \mathrm{cfm})$ each, supply the Operating Gallery. For contamination control purposes, the operating Gallery is maintained at a pressure slightly higher than that of the canyon, but lower than atmospheric pressure and the occupied 271-B building. Exhaust air passes through HEPA filters upstream of the exhaust fans. Each fan services a portion of the Operating Gallery and the Operating Gallery has numerous pieces of equipment and tanks. The cross-sectional area is assumed for this analysis to be reduced by $20 \%$. It is further conservatively assumed that the same airflow velocity occurs as from a single exhaust fan at 50,000 $\mathrm{cfm}$. This provides a conservative airflow velocity of:

$$
v_{\text {airflow }}=\frac{50,000}{14 * 12 * 0.8} / 60 / 3.28=1.89 \mathrm{~m} / \mathrm{s}
$$

Due to the different geometry of the 0perating Gallery floor area compared to that of the AMU area and the higher air velocity, spills of phosphoric acid are further evaluated for the Operating Gallery.

5.1.7.1 Single Tote Leak of Phosphoric Acid In Operating Gallery. This is a similar scenario that has been analyzed for the AMU area, but due to the difference in floor areas and higher ventilation rates for the Operating Gallery, the spill of a single tote is examined. Along the length of the Operating Gallery floor are 10-cm (4-in.) floor drains located approximately 7.3-m (24-ft) apart. Connecting the floor drains is a small trough (channel) 
in the shape of a half circle with a radius of approximately $6.4-\mathrm{cm}$ (2.5-in.). The trough and drains are located approximately $1.5-\mathrm{m}(5-\mathrm{ft})$ from the inner (southern) wall. The trough is designed such that even if a drain strainer is blocked, the trough will allow liquid to flow under the strainer into the drain piping. The slope from both walls to the drains is more pronounced (steeper grade) than in the AMU area. Each tote is approximately $1.5-\mathrm{m}$ (5-ft) wide by $1.5-\mathrm{m}(5-\mathrm{ft})$ deep. A leak from the rear bottom of the tote is assumed to occur and the entire contents spill. The spill will proceed beneath the tote toward the trough located approximately $1.5-\mathrm{m}$ (5-ft) from the rear of the tote. The width of the spill is assumed to be $1.5-\mathrm{m}(5-\mathrm{ft})$, providing $2.32 \mathrm{~m}^{2}$ $\left(25 \mathrm{ft}^{2}\right.$ ) of spill area. The spill will then enter the trough and proceed in both directions to the floor drains. For a moderate leak, the trough will not overflow and continue to discharge the acid down the drain, leading to tanks TK-900 A and TK-900 B located in the bottom floor. Each tank has a 4,160 L (1,100 gal) capacity. The two tanks are compatible with acids. For a massive leak, the trough may initially overflow, but the spill area will rapidly recede to the area of the trough. The trough has a radius of approximately $6.4-\mathrm{cm}(2.5-\mathrm{in}$.$) and the spi11 area with 7.3-\mathrm{m}(24-\mathrm{ft})$ between drains is $0.13-\mathrm{m}_{2} \times 7.3-\mathrm{m}=3.05-\mathrm{m}(5 / 12-\mathrm{ft} \times 24-\mathrm{ft}=10-\mathrm{ft})$. Adding the $2.32 \mathrm{~m}^{2}$ $\left(25-\mathrm{ft}^{2}\right)$ area beneath the tote, the total spill area is $3.25 \mathrm{~m}^{2}\left(35-\mathrm{ft}^{2}\right)$. Using the relationship above of:

$$
\begin{aligned}
A & =3.25 \mathrm{~m}^{2} \\
Z & =0.0079 \\
U & =\text { assume } 1.89(\mathrm{~m} / \mathrm{sec}) \text { air flow } \\
T p & =25{ }^{\circ} \mathrm{C} \\
\text { Qcalc } & =0.08 \times \mathrm{U}^{\frac{3}{4}} \times A \times\left[1+\left(4.3 \times 10^{-3} \times \mathrm{Tp}^{2}\right)\right] \times Z \\
\text { Qcalc } & =0.0122 \mathrm{~kg} / \mathrm{h}=3.4 \mathrm{mg} / \mathrm{sec}
\end{aligned}
$$

The onsite concentration, at $100 \mathrm{~m}$, is calculated as:

$$
\text { Conc. } \begin{gathered}
\left(\mathrm{mg} / \mathrm{m}^{3}\right)=\text { release rate }(\mathrm{mg} / \mathrm{s}) \times X / Q\left(\mathrm{~s} / \mathrm{m}^{3}\right) \\
=3.4 \mathrm{mg} / \mathrm{s} \times 1.15 \mathrm{E}-02 \mathrm{~s} / \mathrm{m}^{3}=0.039 \mathrm{mg} / \mathrm{m}^{3}
\end{gathered}
$$

The offsite concentration at the Fence-Line is calculated as:

$$
\begin{gathered}
\text { Conc. }\left(\mathrm{mg} / \mathrm{m}^{3}\right)=\text { release rate }(\mathrm{mg} / \mathrm{s}) \times \times / Q\left(\mathrm{~s} / \mathrm{m}^{3}\right) \\
=3.4 \mathrm{mg} / \mathrm{s} \times 1.34 \mathrm{E}-05 \mathrm{~s} / \mathrm{m}^{3}=0.000046 \mathrm{mg} / \mathrm{m}^{3}
\end{gathered}
$$

The onsite and offsite consequences are summarized in Table 11. 
Table 11. Predicted Concentrations of Phosphoric Acid (Leak In Operating Gallery).

\begin{tabular}{|c|c|c|c|}
\hline recegton & 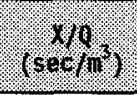 & 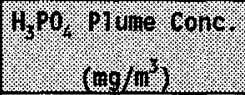 & 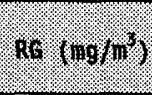 \\
\hline Onsite & $1.15 \mathrm{E}-02$ & 0.039 & 3 \\
\hline Offsite & $1.34 \mathrm{E}-05$ & 0.000046 & 1 \\
\hline
\end{tabular}

Note: $R G=$ risk guideline for $>10^{-2}$ to $\leq 10^{\circ}$.

By comparison, the maximum concentration at the alternate site boundary described in Section 5.1, which considers Highway 240 and the near side of the river, is $0.000064 \mathrm{mg} / \mathrm{m}^{3}$.

5.1.7.2 Massive Spill of Five Totes In Operating Gallery During Seismic Event. This scenario is similar to the seismic event for the AMU area, but modeled slightly different for comparison purposes. If the seismic event results in ceiling debris rupturing all five totes and all 6,245 $\mathrm{L}(1,650$ gal) are spilled, if the Operating Gallery floor was not sloped toward the drains, the spill area would cover the entire floor area to a depth of approximately $6.6-\mathrm{cm}(2.6-i n$.$) . With the slope, the acid would rapidly drain into the$ trough and discharge under the drain strainers into the drain piping. With a steeper slope than the AMU area, the 5 tote spill analyzed previously will bound the consequences for the Operating Gallery, as the total time for the release would be even less. The seismic event could cause a massive destruction of the operating Gallery ceiling and large quantities of debris falling and blocking much of the trough volume. For this case, with 1 arge quantities of debris littering the floor, the use of Clewell (1983) is again used. Clewell cites that for large spillis on uneven ground, by assuming that the average depth is roughly $2.5-\mathrm{cm}(1.0-\mathrm{in}$.$) , a spread factor of 0.04 \mathrm{~m}^{2} / \mathrm{L}$ is appropriate. With $6,245 \mathrm{~L}(1,650 \mathrm{gal})$ of acid, a spill area of $250 \mathrm{~m}^{2}$ results. Using the relationship above of:

$$
\begin{aligned}
A & =250 \mathrm{~m}^{2} \\
Z & =0.0079 \\
U & =\text { assume } 1.89(\mathrm{~m} / \mathrm{sec}) \text { air flow } \\
T p & =25{ }^{\circ} \mathrm{C} \\
\text { Qcalc } & =0.08 \times U^{\frac{3}{4}} \times A \times\left[1+\left(4.3 \times 10^{-3} \times \mathrm{Tp}^{2}\right)\right] \times \mathrm{Z} \\
\text { Qcalc } & =0.938 \mathrm{~kg} / \mathrm{h}=260.6 \mathrm{mg} / \mathrm{sec}
\end{aligned}
$$

The onsite concentration, at $100 \mathrm{~m}$, is calculated as:

$$
\begin{gathered}
\text { Conc. }\left(\mathrm{mg} / \mathrm{m}^{3}\right)=\text { release rate }(\mathrm{mg} / \mathrm{s}) \times \times / Q\left(\mathrm{~s} / \mathrm{m}^{3}\right) \\
=260.6 \mathrm{mg} / \mathrm{s} \times 1.15 \mathrm{E}-02 \mathrm{~s} / \mathrm{m}^{3}=3.00 \mathrm{mg} / \mathrm{m}^{3}
\end{gathered}
$$

The offsite concentration at the Fence-Line is calculated as:

$$
\begin{gathered}
\text { Conc. }\left(\mathrm{mg} / \mathrm{m}^{3}\right)=\text { release rate }(\mathrm{mg} / \mathrm{s}) \times \times / Q\left(\mathrm{~s} / \mathrm{m}^{3}\right) \\
=260.6 \mathrm{mg} / \mathrm{s} \times 1.34 \mathrm{E}-05 \mathrm{~s} / \mathrm{m}^{3}=0.0035 \mathrm{mg} / \mathrm{m}^{3}
\end{gathered}
$$


The onsite and offsite consequences are summarized in Table 12.

Table 12. Predicted Concentrations of Phosphoric Acid (Seismic Event For Operating Gallery).

\begin{tabular}{|c|c|c|c|}
\hline groeptor & (6ector) & heor. phune cono. & 40.919619 \\
\hline Onsite & $1.15 \mathrm{E}-02$ & 3.00 & 5 \\
\hline Offsite & 1.34 E-05 & 0.0035 & 3 \\
\hline
\end{tabular}

Note:

$$
\mathrm{RG}=\text { risk guideline for }>10^{-4} \text { to } \leq 10^{-2} \text {. }
$$

By comparison, the maximum concentration at the alternate site boundary described in Section 5.1, which considers Highway 240 and the near side of the river, is $0.0049 \mathrm{mg} / \mathrm{m}^{3}$.

\subsection{CONTROLS}

\subsection{Floor Drains in AMU Area of 271-B}

For a spill of the contents for one tote, at an annual frequency of $>10^{-2}$, the onsite risk guideline would be slightly exceeded if not for the floor drains in the AMU area. To reduce the possibility of them becoming blocked, a daily check should be made to ensure no debris is blocking the floor drains, as well as checking for loose debris that could block the drains in case of a leak from the totes. This daily inspection should be performed during the time the totes are actually stored in the AMU and any individual tote contains phosphoric acid with a quantity exceeding $265 \mathrm{~L}$ (70 gal). This $265 \mathrm{~L}(70 \mathrm{~L})$ limit is consistent with the currently allowed quantity for nitric acid for the AMU area.

\subsection{Floor Drains in Operating Gallery}

As for a spill of one tote in the AMU area, for the Operating Gallery, if the nearest two drains were blocked, the onsite concentrations would be higher, as a larger spill area would result. A daily inspection for loose debris should be performed for the two nearest drains to the totes stored in the Operating Gallery.

\subsection{Pipe Chase Deflectors}

There are "pipe chases" spaced along the inner (southern) wall that consists of openings in the floor to allow pipes to be routed to the floor below. These openings are surrounded by a berm to prevent any spills onto the operating Gallery floor from entering the floor below. If a tote was located near such a pipe chase opening, and a leak occurred in the tote above the level of the pipe chase berm, the resultant leak could enter the open pipe chase area. To reduce this possibitity, the totes should not be stored any 
HNF-SD-WM-CN-086 REV 0

closer than $1.5-\mathrm{m}(5-\mathrm{ft})$ from the pipe chase. In the situation that this is $1.5-\mathrm{m}(5-\mathrm{ft})$ distance is not practical, a temporary deflector should be provided between the pipes and tote. The deflector should be the height of the tote and extend below the top of the pipe chase berm.

\subsection{REFERENCES}

Clewel1, H. J. III, 1983, A Simple Formula For Estimating Source Strengths From Spills of Toxic Liquids, ESL-TR-83-03, Engineering \& Services Laboratory, Air Force Engineering \& Services Center, Tyndall Air Force Base, Florida.

Hey, B. E., 1996, Supporting Calculations and Assumptions for Use in WESF ISB, WHC-SD-WM-TI-733, Rev. 0, Westinghouse Hanford Company, Richland, Washington.

Hey, B. E., 1994, GXQ 4.0 Program Users' Guide, WHC-SD-SWD-30002, Rev. 1, Westinghouse Hanford Company, Richland, Washington.

Kirk-0thmer, 1978, Encyclopedia of Chemical Technology, 3rd Edition, Wiley and Sons, New York, New York.

NIOSH, 1990, Registry of Toxic Effects of Chemical Substances, U.S. Department of Health and Human Services, National Institute for 0ccupational Safety and Health, Washington, D.C.

Perry, 1984, Perry's Chemical Engineering Handbook, 6th ed., McGraw-Hi11, Inc., New York, New York.

WHC, 1994, A Model for Predicting Respirable Releases from Pressurized Leaks, WHC-SD-GN-SWD-20007, Westinghouse Hanford Company, Rich1and, Washington.

WHC, 1996a, Safety Analysis Manual, WHC-CM-4-46, Release 18, Westinghouse Hanford Company, Richland, Washington.

WHC, 1996b, B Plant Interim Safety Basis Accident Analysis, WHC-SD-WM-SARR030, Westinghouse Hanford Company, Richland, Washington.

WSRC, 1993, Toxic Chemical Hazard Classification And Risk Acceptance Guidelines For Use In D.0.E. Facilities, WSRC-MS-92-206, Rev. 1, Savannah River Technology Center, Westinghouse Savannah River Company, Aiken, South Carolina. 
HNF-SD-WM-CN-086 REV 0

This page intentionally left blank. 
HNF-SD-WM-CN-086 REV 0

APPENDIX A

SPRAY MODEL RESULTS OF PHOSPHORIC SPRAY

RELEASE FROM AMU AREA TO SCALE TANK

AND WITHIN CANYON AREA

A-1 
HNF-SD-WM-CN-086 REV 0

This page intentionally left blank. 
SPRAY Version 3.0

May 3, 1994

Spray Leak Code

Produced by Radiological \& Toxicological Analysis

Westinghouse Hanford Company

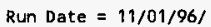


SPRAY Version 3.0

May 3, 1994

Spray Leak Code

Produced by Radiological \& Toxicological Analysis Westinghouse Hanford Company

Run Date $=11 / 02 / 96 /$

Run Time $=09: 57: 35.30$

INPUT ECHO:

c SPRAY Version 3 Input Deck

c mode iflow iopt

$$
2 \text { mode iflow lop }
$$

c B Plant Phosphoric Transfer Within Canyon Area

c MODEL OPTIONS:

$c$ mode $=1$ then orifice leak with friction assumed

c 2 then slit leak with friction assumed

c iflow $=0$ Reynold's number determines friction relation (i.e.

c laminar or turb.)

$=1$ friction based on Laminar relation

$=2$ friction based on turbulent relation

iopt $=\mathrm{T}$ then opt imal diameter search performed

$=F$ then no optimal search

PARAMETER INPUT:

Initial slit

Width or

Orifice Dia.

(in)

slit

Slit or

Orifice

Depth

(in) (in)

$\overline{1.00000 E-03} \quad \overline{2.00000 E+00} \quad \overline{1.54000 \bar{E}-01}$

Absolute

Surface

Roughness

(in)

Pressure 0.00006 tube 0.61 and 0.98 for sharp edge orifice

Differential 0.0018 steel 1.00 and 0.98 for rounded orifice

(psi) 0.0102 iron $i .00$ and

0.82 for square edge orifice

$1.00000 \mathrm{E}+02$

$\overline{1.80000 \mathrm{E}-03}$

$\overline{6.10000 \mathrm{E}-01}$

$\overline{9.80000 \overline{0}-01}$

Fluid

Dynamic

Viscosity

Respirable

RR Fitting

Specific

(centi-poise)

$(\mu \mathrm{m})$

(q)

$\overline{1.57300 E+00}$

$1.37250 \mathrm{E}+01$

$5.00000 \mathrm{E}+01$

$2,40000 \mathrm{E}+00$

\section{MESSAGES:}

slit Model

Code search for opt imal equivalent diameter.

Friction factor based on laminar flow.

OUTPUT :

Liquid Velocity $=7.18 E+01 \mathrm{ft} / \mathrm{s} \quad 2.19 E+01 \mathrm{~m} / \mathrm{s}$

Reynolds Number $=8.92 \mathrm{E}+02$ Laminar $\mathrm{Flow}$

Sauter Mean Diameter $=1.61 \mathrm{E}+02 \mathrm{\mu m}$

Optimum slit Width $=7.02 \mathrm{E}-03$ in $\quad 1.78 \mathrm{E}-04 \mathrm{~m}$

Respirable Fraction $=2.41 \mathrm{E}-03$

Total Leak Rate $=1.92 \mathrm{E}+00 \mathrm{gpm} \quad 1.21 \mathrm{E}-04 \mathrm{m3} / \mathrm{s} \quad 1.90 \mathrm{E}+02 \mathrm{~g} / \mathrm{s}$

Respirable Leak Rate $=4.61 \mathrm{E}-03 \mathrm{gpm} \quad 2.91 \mathrm{E}-07 \mathrm{m3} / \mathrm{s} \quad 4.58 \mathrm{E}-01 \mathrm{~g} / \mathrm{s}$ 


\section{CHECKLIST FOR PEER REVIEW}

Document Reviewed: $\frac{H F}{K N}-5 D-i S A 1-C N-086$ REV OO

Scope of Review: ENTIEE DICAMENT

$\frac{\text { Yes No NA }}{[][][X] \text { * }}$

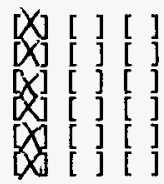

W [ ] [ ]

[X] [ ] [ ]

[X] [ ] [ ]

D] [ ] [ [ ]

$[X][][]$

X] $\left[\begin{array}{lll}{[} & {[} & {[}\end{array}\right]$

W [ ] [ ]

[ ] [ ] [X]

[ ] $[X] *$

X] [ ] [ ] Document approved.

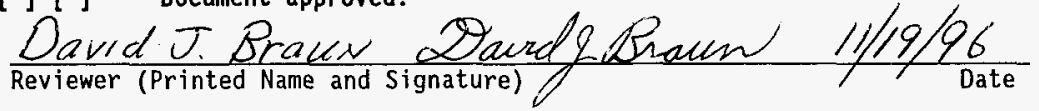

* Any calculations, comments, or notes generated as part of this review should be signed, dated and attached to this checklist. Such material should be labeled and recorded in such a manner as to be intelligible to a technically qualified third party.

Previous reviews complete and cover analysis, up to scope of this review, with no gaps.

Problem completely defined.

Accident scenarios developed in a clear and logical manner.

Necessary assumptions explicitly stated and supported.

Computer codes and data files documented.

Data used in calculations explicitly stated in document.

Data checked for consistency with original source information as applicable.

Mathematical derivations checked including dimensional consistency of results.

Models appropriate and used within range of validity or use outside range of established validity justified.

Hand calculations checked for errors. Spreadsheet results should be treated exactly the same as hand calculations.

Software input correct and consistent with document reviewed.

Software output consistent with input and with results reported in document reviewed.

Limits/criteria/guidelines applied to analysis results are appropriate and referenced. Limits/criteria/guidelines checked against references.

Safety margins consistent with good engineering practices.

limits.

Results and conclusions address all points required in the problem statement.

Format consistent with appropriate NRC Regulatory Guide or other standards

Review calculations, comments, and/or notes are attached. 
$\underset{\text { KN }}{H N F-S D-W M-C N-086 \text { REV Off }}$

This page intentionally left blank.

A- 6 
DISTRIBUTION SHEET

\begin{tabular}{|c|c|c|c|c|c|}
\hline \multirow{2}{*}{$\begin{array}{l}\text { To } \\
\text { Distribution }\end{array}$} & \multirow{2}{*}{\multicolumn{3}{|c|}{$\begin{array}{l}\text { From } \\
\text { SAR Engineering Services }\end{array}$}} & \multicolumn{2}{|l|}{ Page 1 of 1} \\
\hline & & & & \multicolumn{2}{|c|}{ Date $\quad 1 / 2 / 97$} \\
\hline \multirow{2}{*}{\multicolumn{4}{|c|}{$\begin{array}{l}\text { Project Title/Work Order } \\
\text { B Plant Phosphoric Acid USQ }\end{array}$}} & \multicolumn{2}{|c|}{ EDT No. $\quad 619952$} \\
\hline & & & & \multicolumn{2}{|l|}{ ECN No. $\quad N / A$} \\
\hline Name & MSIN & $\begin{array}{l}\text { Text } \\
\text { With All } \\
\text { Attach. }\end{array}$ & Text Only & $\begin{array}{l}\text { Attach./ } \\
\text { Appendix } \\
\text { Only }\end{array}$ & $\begin{array}{l}\text { EDT/ECN } \\
\text { Only }\end{array}$ \\
\hline
\end{tabular}

Central Files (original +2 copies)

Chalk, S.E.

Docket Files (2 copies)

Dodd, E.N. Jr.

Gray, B.J.

Hafla, E.R.

Hill, M.A.

Johnson, L.E.

Robbins, E.D.

Roege, P.E.

RAU, A.B. (2copies)

$\begin{array}{ll}\text { A3-88 } & X \\ \text { A2-25 } & X \\ \text { B } 1-17 & X \\ \text { S4-66 } & X \\ \text { S6-81 } & \\ \text { S6-60 } & X \\ \text { S4-66 } & X \\ \text { A2-25 } & \\ \text { S6-59 } & \\ \text { S4-66 } & X \\ \text { A2-2S } & X\end{array}$

$X$
$X$

$54-66$

A. $2-25$

$x$ 